\title{
Replication Protein A 14 kDa
}

National Cancer Institute

\section{Source}

National Cancer Institute. Replication Protein A 14 kDa. NCI Thesaurus. Code C116639.

Replication protein A $14 \mathrm{kDa}$ (121 aa, $\sim 14 \mathrm{kDa}$ ) is encoded by the human RPA3 gene. This protein plays a role in replication, recombination and repair of DNA. 